\title{
Authenticity and modernity \\ Concepts of past and present that shape music history
}

\section{Prof. Dr. Soren Sorenson*}

Music example 1:

Franz Schubert. String Quartet I G-major, op. 161. Third movement. Last measures of Scherzo, first measures of Trio.

\section{Introduction:}

This music sounds as if 'was coming from afar. From the world of yesterday.

Franz Schubert cuts and paste a popular dance tune - the Austrian Ländler - in his advanced string quartet as a sounding symbol of that loss of immediacy that seems to be the an indispensable part of the modern condition.

Here, I will start my contribution to our conference's discussion of the issue of 'identity of music between authenticity and contemporarity'. The Ländler's dreamlike evocation of a pre-modern rural world where 'such things as home, nature and immediate life' 1 still are not uprooted by modernity here stands for the feeling of loss of authenticity that I claim to be 'inscribed in modernity'.

By this, I signal that I focus on a particular aspect of the authenticity debate. What I particularly have in mind is music's contribution to the discussion of how we in the modern world access our pasts and how our views to the past take part in the negotiation of modern cultural identities.

In the following, I begin with some comments on early twentieth-century European modernism's struggle with the issue of valid representation the musical past in contemporary music. After this, I present a brief survey of more recent

${ }^{*}$ Professor of Musicology and Orientalist, University of Copenhagen - Danemark.

1 Schnebel, D. 1979. "Klangräume -Zeitklänge", in Musik-Konzepte, Sonderband Franz Schubert, edited by Metzger, K.H. \& Reihn, R. München: text + kritik. 90

مجلة علوم وفنون الموسيقى - كلية التربية الموسيقية - المجلل با؛ - عدد خاص "الموسيقى وهوية الشعوب" - أغسطس ا.r.rم 
debates on music and historiography in Western musicology. Finally, I will turn to a famous example from mid-twentieth-century Egyptian music history.

Part 1.

\section{European modernism and neo-classicism.}

The connection between modernity and the quest for authenticity is particularly evident in historical periods marked by rapid processes of modernization. So, for instance in Europe in the years before and after World War 1. Whit in a short span of years, modernity showed both its great liberating potential and its immense power of destruction - and European music reacted with the great sensitivity.

This showed in the advent of modernist trends of unprecedented radicalism. But it also showed in a sharpened historical awareness and a strong sense of commitment to tradition.

This is particularly evident by the German composer Arnold Schoenberg who tirelessly endeavored to convince the public that his modernist innovations, far from being the product of whimsical fashion, were necessary consequences of evolutionary forces within the European tradition of instrumental music itself.

"The method of composing with twelve tones grew out of a necessity" 2 , he famously stated, referring both to his so-called "free atonal period" and to his later twelve-tone technic. With regard to the first, he argued that his compositions from 1908 and onward with no reference to a tonic root or key was the consequence of the widening and weakening of the tonal forces in compositions by his great predecessors such as Richard Wagner and Richard Strauss. With regard to the latter, he argued that the fundamental criterion of the twelve-tone technique, the structural equivalence of the inverted and retrograde forms of the original twelvetone set, was unconsciously preconceived in music of the great German tradition before him.

2 Schoenberg, A. 1975 (1941). "Composition with twelve tones". Style and Idea. New York: St. Martin's Press. 216

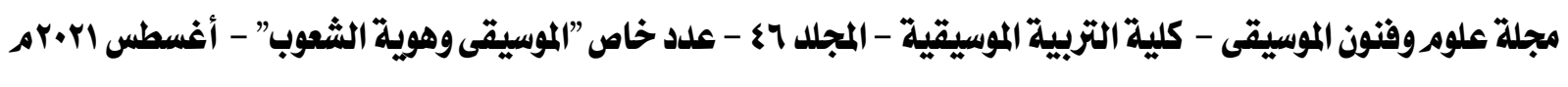


This figure of thought, that contemporary music - and not least radically new music - represents a necessary consequence of that which preceded it, refers to the philosophy of G.F.W. Hegel. The teaching of this German philosopher implies that the authenticity of cultural transmission is only secured by a historical process that includes rupture and the advent of radically new cultural forms on humanity's road to truth and freedom.

This idea was commonplace in academic musical discourse in the Germanspeaking countries at least since mid-19th-century and it remained incredibly influential and persistent. In the academic milieu in Denmark that I entered as a young man in the late 1970ies, it was still was generally accepted.

At this time, before postmodernism challenged the high-modernism-inclination of academic north-European contemporary music environment, it was customary to view Schoenberg's twelve-tone music and Igor Stravinsky's neo-classicism as antipodes. We viewed them as representations of two conflicting models of relating to the past - and usually we favored Schoenberg's model and shared his belief in a historical necessity, where past forms are conceived of as indispensable preconditions for the new, but themselves left back as surpassed and obsolete. Stravinsky's neo-classicism on the other hand, we viewed as the denial of the commitment to a binding continuous tradition, as arbitrary re-use and rehabilitation of past forms and genres and maybe as expressions of naïve dreams of returning to cultural forms and values of some golden age before the doubts and insecurities of the modern condition.

Only later, postmodernism's radical denial of concepts of unilineal historical progress and teleological thinking in the Hegelian style, made us revise our judgment. We now recognized the presence of neo-classicist tendencies on both sides. We became more aware of the similarities between works by Schoenberg and Stravinsky from the 1920ties.

So for instance, both Arnold Schoenberg's Quintet for Wind Instruments op.26 and Stravinsky's Octet for Wind Instruments employ conventional musical form.

مجلة علوم وفنون الموسيقى - كلية التربية الموسيقية - المجلل با؛ - عدد خاص "الموسيقى وهوية الشعوب" - أغسطس ابrمه 
First movement of Schoenberg's Quintet for Wind Instruments is a clear-cut sonata form of that elaborate type we know from Joseph Haydn and onwards. It is neatly crafted with primary and subsidiary themes, exposition, development and recapitulation.

According to Schoenberg himself, this return to classical musical form evidenced that music through his new twelve-tone technic had regained the ability to foster great self-reliant 'absolute' musical constructs of the kinds that formerly were based on the integrative power of functional harmony.

We will hear the beginning of the first movement of Arnold Schoenberg's Quintet for Wind Instruments, beautifully played by the Basel Wind Ensemble.

Music example 2:

Arnold Schoenberg: Quintet for Wind Instruments, op 26 (1923-24). First movement, exposition.

With his Quintet for Wind Instruments, Schoenberg returned to conventional musical form after the radical experiments of the expressionistic, free atonal works from the years before World War I, so indeed also in this case, we have to do with a kind a neo-classicism.

Still, Schoenberg's twelve-tone version of post-World War I neo-classicism differs radically from Igor Stravinsky's. It is true that they both viewed to the musical past. But they viewed it differently in various aspects.

1) Stravinsky viewed to another past. So for instance, the first movement of his Octet for Wind Instruments is a pastiche of a pre-classical, early 18th-century genre of instrumental music called 'sinfonia' not be confused with later 'symphony'. The 'sinfonia' was typically a lighthearted instrumental piece for string and wind instruments used as prelude for operas or at festive, typically outdoor events. That is say that Stravinsky dealt with a repertoire that was no

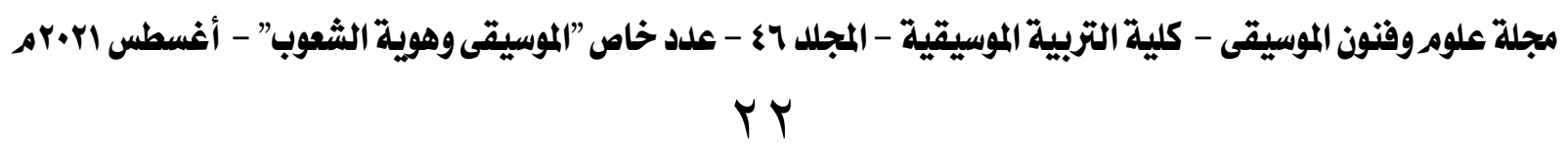


longer a living part of the musical tradition, transmitted to twentieth-century music rather by scholars' historical research than by musicians' performative practice.

2) Stravinsky had another approach to the past. By Schoenberg, we observe the coexistence of the a-tonal serially arranged material and a classical form that he treats seriously and respectfully. By Stravinsky on the other hand, tonality indeed is present, but not as conventional tonality. It is as if the very concept of tonality has had to be reinvented, restored and somehow alienated. And the form itself is not just there as a matter of fact. It is also aleinated. It is playfully de-familiarized as viewed from afar or though a prism.

Stravinsky's sinfonia movement starts with a slow introduction leading to the sonata-allegro. When we hear it, pay notice to the de-familiarizing of a conventional model of the allegro-theme. The passage is shaped over the mold: theme-head followed by a series of sequences leading to the cadence. The convention, however, is disrupted by the incursion of measures of $5 / 8$ and $3 / 4$ in the $2 / 4$ meter and through the so to speak 'independent life' of the Bb-trumpet that adds to the confusion of the cadence.

Music example 3.

Igor Stravinsky: Octet for Wind Instruments (1923). First movement 'Sinfonia'. Slow introduction and first measures of Allegro.

Part 2

\section{Reviving forgotten music}

Stravinsky's recourse to a genre that at his time no longer was part of the concert hall repertoire but transmitted through the work of music historians, leads us to another important aspect of the authenticity issue.

A great part of classical Western music played today has not been continuously present as part of the concert repertoire since it was written. For shorter or longer spans of time, it has not been part of living traditions of musical performance. It

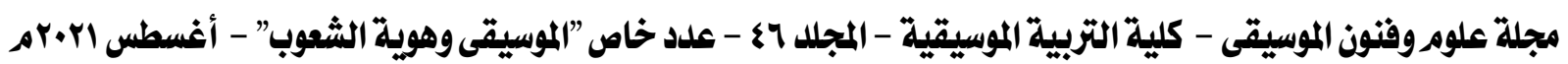


only survived as written historical sources, and it only gained its position as part of the modern repertoire through deliberate revivalist efforts.

The most famous example is the music of Johann Sebastian Bach. The greater part of the music of this great musician was forgotten (or known only by minor groups of musical connoisseurs) and it was made part of the modern repertoire only through musicology's philological work with the sources. The same goes for pre-classical - baroque, renaissance and medieval - secular music in general. We know this early music through written sources handed down to us, and we are only able to read and play it, because musicology has edited the sources and published them in modern accessible forms. Philological work with that purpose was at the core of European musicology in its formative years in the 19th century, and obviously, the main concern at that time was the authenticity of the transmitted text.

Only later, with the advent of 'the early music movements' in the early twentieth century a quest for the authentic performance was added to the quest for the authentic musical text. This implied a new focus on other types of source material than the written music. This could be treatises and methods on playing techniques, treatises on tuning and temperament, accounts of performances in journals and literature, books on instruments and instrument building and more of that like.

The value of the quest for an authentic performance practice, however, is subject to much dispute. In some case, the very idea of the possibility of reaching a historically correct way of performing early music is ridiculed and the ideology underlying the whole project challenged.

The most noteworthy contribution to this discussion came in 1995 with the American musicologist Richard Taruskin's antology Text and Act3. Taruskin argued against that special alliance between historical research and musical performance that developed through the twentieth century in 'early music' or 'authentic performance practice' circles. In his view, it represented an illegitimate

${ }^{3}$ Taruskin, R. 1995. Text and Act. Essays on Music and Performance. Oxford. Oxford University Press.

مجلة علوم وفنون الموسيقى - كلية التربية الموسيقية - المجلل با؛ - عدد خاص "الموسيقى وهوية الشعوب" - أغسطس ابrمه 
intrusion of criteria based on textual historical research in a field where the musicians' situational choices should reign. Moreover, and as if he wanted to strengthen the connection to the our modernity and authenticity discussion, he argued that the rise of the authority of the textual historical evidence and the decline of the authority of the performer's situational choices in the performance are genuine modernist occurrences.

Part 4

\section{Western Music history and 'orientalism'.}

Historiography' in this sense is the study of writing history and of written histories and this study is based on the assumption that historical knowledge never reaches us unmediated. Writing of history is necessarily tainted by the horizons and perspectives of it authors. Based on this acknowledgement, 'historiography' investigates cultural, ideological and political conditions that frames and influences history writing as well as the traces left of these conditions in the actual historical accounts.

Particularly one contribution to this trend of critical historical reflection made a strong impact on me when it appeared in 1991. It is written by the American early music scholar Leo Treitler who also diligently took part in discussion of new trends in Western musicology at that time. The article's tricky title "The Politics of Reception: Tailoring the present as the fulfillment of a desired past" 4 expresses well how needs and desires of our present is mirror-like reflected in the picture of the past that we conjure up in our historical narratives. In Treitler's rhetorically pointed view, history writing conjures up the past that we desire because it can be understood as the background for the present that we want to see ourselves in.

The specific object of Leo Treitler's article is the history of the Gregorian chant - a core repertoire of music in the Catholic Church - and he convincingly

4 Tretler, L. 1991. "The Politics of Reception: Tailoring the present as the fulfillment of a desired past". Journal of the Royal Musical Association Vol. 116, No. 2. 280-298

مجلة علوم وفنون الموسيقى - كلية التربية الموسيقية - المجلد 7؟ - عدد خاص "الموسيقى وهوية الشعوب" - أغسطس اY.rمر 
demonstrates that the ways this part of European music history has been narrated is a matter of much more than music.

Treitler's critical reading reveals that the history of the Gregorian chant tells not only about this specific musical genre but also quite a lot about how Europeans wished to view themselves - and particularly, how they desired to view themselves vís a vís the 'oriental other'. He demonstrates how the part of the repertoire that is most clear-cut structured and least marked by florid ornamentation is preferred and how the formal properties - cadence patterns, segmentation and varied repetition are interpreted as manifestations of Western rationality and juxtaposed the florid, ornamental style of other parts of the repertoire that is dubbed 'oriental'. In short, Treitler finds in Western historical narratives on the Gregorian chant exactly that kind of dichotomizing thinking that Edward Said analyzed in his Orientalism from 1978. That is, a view to the world where the Westerner projects all the features, that he cannot accept as a part of himself, on his 'oriental other'.

It is my personal experience that the idea of such 'fundamental differences' soon disappears, when you honestly engage in focused in-depth-studies of products of other cultures.

One example from my recent research:

Part 5.

\section{Ahmad Shawqi, Riad as-Sunbati, Umm Kulthum: Nahj al-Burda}

Music example 4.

$$
\begin{aligned}
& \text { Ahmad Shawqi, Riad as-Sunbati, Umm Kulthum: Nahj al-Burda (1946). } \\
& \text { أحل سفك دمي في الثهر الحرم - ريم على القاع بين البان والعلم }
\end{aligned}
$$

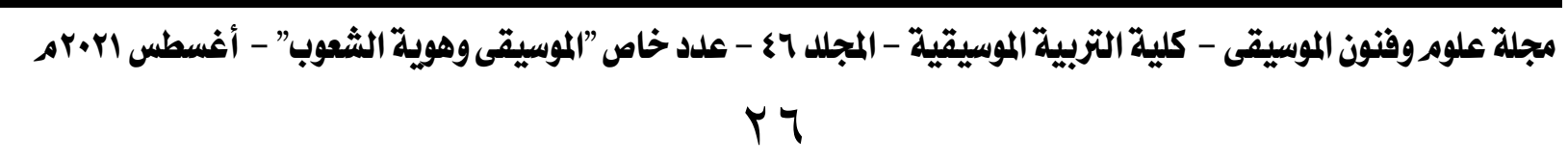


We heard Umm Kulthum singing a few strophes of the qasida Nahj al-Burda with music by Riad as-Sunbati and text by Ahmad Shawqi. This piece of vocal music enacts relations to Arab cultural history in several dimensions all of which can be subject to controversies concerning its validity or authenticity - controversies strikingly similar to contemporary European controversies.

This is particularly evident as far as the text is concerned. This was written in the early 20th century by Ahmad Shawqi - one of Egypt's most renowned neoclassicist poets.

But Ahmad Shawqi didn't write this poem on an empty slate. As its title Nahj al-Burda indicates, it is written 'in the way of the Burda'. That is, Ahmad Shawqi wrote his Burda-poem as a mu'arada to a previous poem -the famous devotional qasida al-Burda written by the Imam al-Busiri in the thirtieth century. A mu'arada, in the literary meaning of this word, is an emulation, rewriting or respectful pastiche on a previous poem. It is a kind of a handshake from one poet to a predecessor and former master of the craft - and it is expected not only to reuse part of the model's poetic form, technique and lexicon, but also to surpass it in poetic mastery and maybe even size. Often - and obviously so in Ahmad Shawqi it also means rereading and revitalizing the poem and directing its effects towards a contemporary social, cultural and political reality. Thus writing a mu'arada is an immediate and obligating way to address the literary past and to give ancient traditions presence and significance in a new historical situation.

Today Ahmad Shawqi - the prince of poets - is firmly established in the Egyptian literary canon. But in his own days the neo-classicist inclination of the this poet was disputed in ways not dissimilar to the dispute on European neoclassicism of the same period. Another great Egyptian, the writer, critic and reformer Taha Hussein, harshly criticized Shawqi's dependence on traditional poetic forms that in his view limited his artistic freedom and he linked this with Shawqi's noble birth and his subordinate position as a court poet. And by the way: he confronted Ahmad Shawqi's subordinate position and neo-classicist inclination

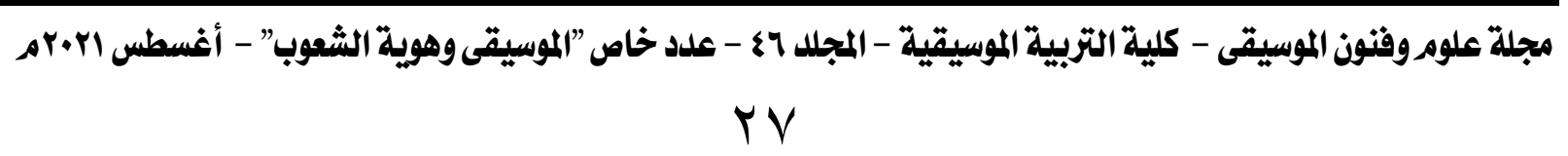


with the position of the great French modernist Charles Baudelaire that in Taha Hussein's view embodied the highest ideal of the literary freedom and personal independence.5

The poem was set in music by Riad al-Sunbati and premiered by Umm Kulthum in 1946. That is, in a period that should soon be followed by the revolution of 1952 and - some years later - the reign of Gamal 'abd al-Nasser - and it has been observed that its plea for "restauration of Arab-Islamic political power and dignity coincided with aspirations of Arab and Egyptian nationalism in the Nasserite Era".6 Accepting this, we can observe that relations between several eras and historical situations are in play. Mid-twentieth-century cultural and political aspirations meet with early twenty-century political contexts in a poem that refer far back in Arab-Islamic culture.

This mid-twentieth-century situation in Egypt generated a need for an Arabic neo-classicism in music that according to the American scholar Virginia Danielson was met be the composition of Riad as-Sunbati. I quote: "Riyad al-Sunbati became a neoclassicist per excellence with his qasa'id. He followed the path of some older colleagues, aimed to use historically Arabic raw materials, most notable a range of maqamat, stepwise melodic movement, and genres such as the qasida."7 I will argue that exactly the combination of these traditional Arab musical features and the innovations of as-Sunbati's composition allows it to convey the some 50-yearolder poem to the audience anno 1946 and to give a glimpse of the more distant past of al-Busiri's al-Burda. as-Sunbati combines a new extensive dramatic design in a composition that at the same time summarizes characteristics of the lateninetieth-early twentieth-century wasla and gives the tradition of tarab a new presence in the modern concert hall.

Not to speak of the voice of Umm Kulthum that embraces it all!

${ }^{5}$ Hussein, T: Hāfiz wa Shawqī, p.59-60. Publisher, year?

6 Stetkevych, S.P. 2010. The Mantle Odes. Arabic Praise Poems to the Prophet Muhammad. Bloomington \& Indiapolis: Indiana University Press. 2010, 232

7 Danielson, V. 1992. The Voice of Egypt. Umm Kulthum, Arab Song, and Egyptian Society in the Twentieth Century. Chicago: Chicago University Press. 115

مجلة علوم وفنون الموسيقى - كلية التربية الموسيقية - المجلل با؛ - عدد خاص "الموسيقى وهوية الشعوب" - أغسطس ا.r.rم 


\section{Conclusion}

I have attempted to demonstrate how contemporary music of the twentieth century was permeated with concern for the validity of its relation to the past, how various models for relation to the past have been in play, and how musicology has reflected on sensitive issues of historical authenticity. By doing so, I opened a broad field of topics for discussion, and I have no intention of forcefully close them again for the gain of a smoothly rounded lecture.

Instead, let me conclude by this:

It seems to be part of the modern condition to be in doubt of the authenticity of one's relation to history and to device various and competing strategies to cope with this doubt. Throughout the twentieth century, art and music proved a valuable site for experiments with such strategies and it is my firm belief that music still has an important role to play in this context.

A valid - authentic - relation to the past is not achieved passively. It must be won over and over again - actively! Therefore, it is my sincere hope that a young generation of musicians and musicologists with strong desires for discovery and experiment will continue to explore our shared musical past and bring its treasures into our time in words and in music that I could not imagine or even dream of without their help.

Thank you for your patience. 